\begin{tabular}{|l|l|l}
\hline Received: Desember 2019 & Accepted: Maret 2020 & Published: April 2020
\end{tabular}

\title{
Rancang Bangun Dc - Dc Converter Berbasis Microcontroller STM32F4 dan Matlab/Simulink
}

\author{
Hilmansyah ${ }^{1^{*}}$, Restu Mukti Utomo ${ }^{2}$ \\ ${ }^{1,2}$ Program Studi Teknologi Listrik - Jurusan Teknik Elektro - Politeknik Negeri Balikpapan \\ "hilmansyah@poltekba.ac.id
}

\begin{abstract}
$D C-D C$ converters are widely applied to renewable energy, solar cells, battery charging systems and electric cars. One method in DC - DC converter is buck converter. In a buck converter, the output voltage is smaller than the input interval. In this paper, the buck converter is designed using a MATLAB / Simulink based STM32F4 microcontroller, TLP521 as a safety connection for buck and STM32F4 converters, IGBT FGH75T65UPD as a switching component, and IR 2111 which is also used as a driver gate for IGBT. The STM32F4 Planting Program from MATLAB / Simulink uses waijung blockset. The input voltage on the designed buck converter is $35 \mathrm{~V}$ with an output voltage of $3.5 \mathrm{~V}$ to 31.5 $V$ with a maximum switching frequency at IGBT of $100 \mathrm{kHz}$, voltage riple is arround $0.1 \%$ and current riple is arround $10 \%$. Data conversion on the experimental results on the duty cycle will be announced on the output, output current and efficiency of the buck converter.
\end{abstract}

Keywords : DC-DC Converter, buck converter, STM32F4, MATLAB/Simulink

\begin{abstract}
Abstrak
DC - DC converter banyak diaplikasikan pada renewable energy, sel surya, sistem pengecasan baterai dan mobil listrik. Salah satu metode pada DC - DC converter adalah buck converter. Pada buck converter, tegangan keluaran lebih kecil dari tengangan masukkannya. Pada paper ini, buck converter didesain menggunakan microcontroller STM32F4 berbasis MATLAB/Simulink, TLP521 sebagai pengaman rangkaian daya buck converter dan rangkaian kendali STM32F4, IGBT FGH75T65UPD sebagai komponen switching, dan IR 2111 yang berfungsi sebagai gate driver untuk IGBT. Penanaman program STM32F4 dari MATLAB/Simulink menggunakan waijung blockset. Tegangan masukan pada buck converter didesain sebesar $35 \mathrm{~V}$ dengan tegangan keluaran sebesar 3,5 V sampai dengan $31,5 \mathrm{~V}$ dengan frekuensi switching pada IGBT maksimum sebesar $100 \mathrm{kHz}$, riple tegangan sebesar $0,1 \%$ dan riple arus sebesar $10 \%$. Data pada hasil eksperimen menunjukkan bahwa perubahan pada duty cycle akan berpengaruh pada tegangan keluaran, arus keluaran dan efisiensi dari buck converter.
\end{abstract}

Kata kunci : DC-DC converter, buck converter, STM32F4, MATLAB/Simulink

1. Pendahuluan

Pengembangan teknologi converter terutama DC - DC converter mengalami pengembangan yang cukup signifikan dikarenakan aplikasinya pada bidang renewable energy, electric vehicle, dan microgrid [1], [2], [3], [4], [5]. Buck converter merupakan salah satu dari DC - DC converter yang mengkonversi tegangan DC ke tegangan DC yang lebih rendah. Buck converter dapat diaplikasikan pada sistem pengisian baterai pada photovoltaic systems [6]. Pada institusi pendidikan, buck converter telah dikembangkan di berbagai aspek seperti : pengembangan metode switching, teknik pemrogaman untuk pulsa switching, teknik 
simulasi, aplikasi di lapangan dan lain sebagainya. Pengembangan metode switching pada buck converter lebih difokuskan pada strategi pengatuan switching untuk buck converter dan asynchronous PWM [7], [8] sedangkan pada sistem simulasi, buck converter dikembangkan menggunakan Model in The Loop (MIL), Hardware in The Loop (HIL), FPGA in The Loop (FIL) dan Processor in The Loop (PIL) [9], [10], [11], [12].

Pada paper ini, Pulse Width Modulation (PWM) pada buck converter dibangkitkan melalui microcontroller STM32F4 dengan menggunakan waijung blockset pada MATLAB/Simulink. Hasil pengukuran sinyal keluaran buck converter diukur secara manual menggunakan oscilloscope dan digital multimeter.

\section{Metoda Penelitian}

\subsection{Buck Converter}

Pada penelitian ini, buck converter di desain untuk mengonversi tegangan sumber 10 $\mathrm{V}$ menjadi $\pm 3 \mathrm{~V}$ dengan nilai duty cycle yang bervariasi. Pada gambar 1, alur pengambilan data diawali dengan pengaturan nilai Analog to Digital Converter (ADC) 12 bit $(0$ - 4095). Pengaturan nilai ADC dilakukan dengan memutar potensiometer. Tahap selanjutnya adalah nilai 12 bit ADC akan dirubah menjadi nilai prosentase $(0 \%-100 \%)$ sesuai degan nilai duty cycle pada PWM.

Nilai duty cycle yang dimiliki oleh PWM dibatasi untuk rentang tegangan tertentu. PWM pada STM32F4 dibangkitkan melalui timer 1 $\mathrm{CH}$ 1. Data yang digunakan pada paper ini meliputi data perhitungan teori dan praktikum. Data teori didapatkan melalui perhitungan perhitungan teoritis pada buku, paper dan referensi pustaka ilmiah. Data praktikum didapatkan melalui percobaan di laboratorium.

Pada gambar 2, menunjukkan desain dari rangkaian buck converter yang digunakan pada pengujian praktikum. Pada tahap awal, STM32F4 ditanamkan program dari PC menggunakan MATLAB/Simulink dan waijung blockset. Tegangan supply untuk STM32F4 menggunakan power supply DC $5 \mathrm{~V}$.
Potensiometer digunakan untuk memberikan data referensi berupa pembacaan nilai ADC oleh pin ADC (pin A5). ADC yang digunakan pada paper ini adalah ADC 12 bit dengan resolusi sebesar $4096(0-4095)$.

Pembacaan nilai ADC dikonversi menjadi duty cycle pada PWM. PWM pada paper ini dibangkitkan menggunakan timer 1 channel 1 pada pin A8 dari STM32F4. IC TLP 521 merupakan IC optocoupler yang berfungsi sebagai pengaman dan perubah nilai tegangan maksimum PWM dari $3 \mathrm{~V}$ menjadi $12 \mathrm{~V}$. IR 2111 merupakan IC driver untuk MOSFET dan IGBT. IR 2111 mendapatkan tegangan masukan dari TLP521 dan diteruskan sebagai sinyal switching untuk IGBT pada rangkaian buck converter.

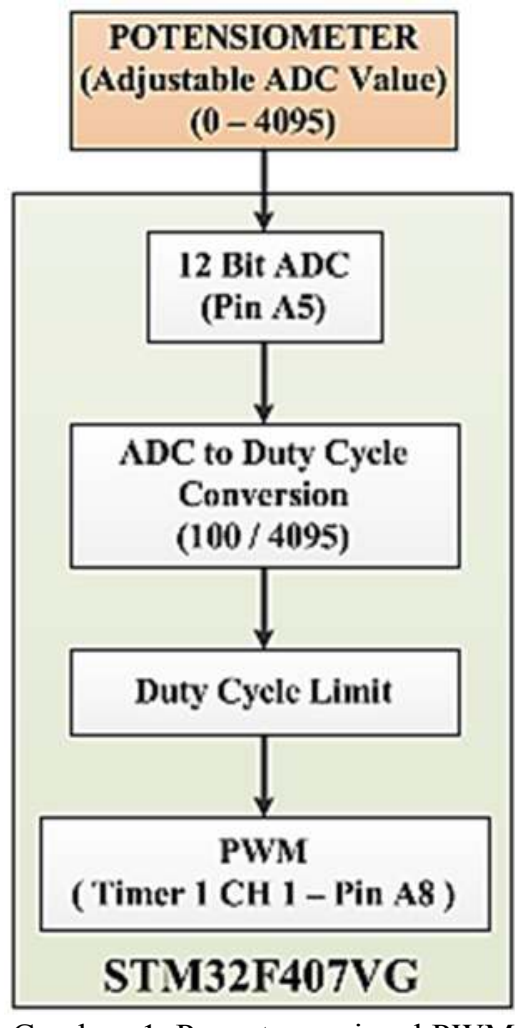

Gambar 1. Pengaturan sinyal PWM 


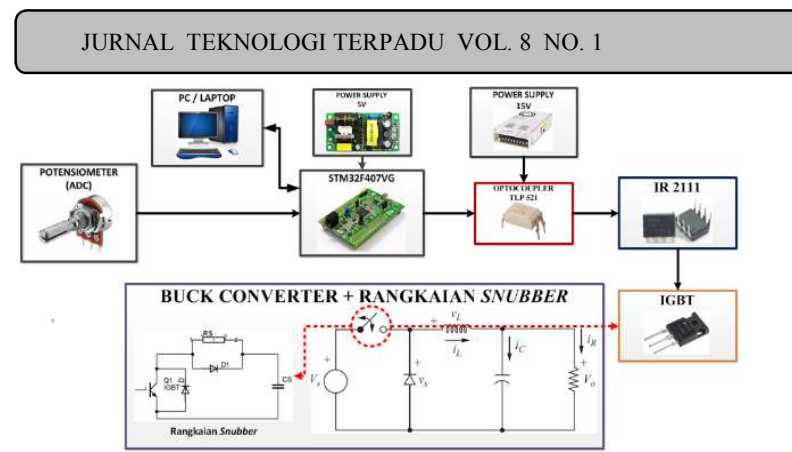

Gambar 2. Design sistem buck converter

\subsection{STM32F4 pada MATLAB/Simulink}

Pembuatan dan penanaman program pada STM32F4 dapat dilakukan dalam beberapa cara, seperti CooCox CoIDE, Keil uVision sampai pemrogaman yang dapat digunakan untuk menerapkan teknologi simulasi seperti HIL dan FIL. Salah satu cara penanaman program STM32F4 yang berbasis HIL adalah dengan menggunakan MATLAB/Simulink yang diintegrasikan dengan waijung blockshet dan ST-Link Utility.

\section{Hasil Penelitian}

Rancangan buck converter ini ditunjukkan oleh gambar 2. Sumber tegangan menggunakan dua buah adjustable power supply 30V / 3A yang dirangkai secara paralel untuk mendapatkan tegangan masukan $35 \mathrm{~V}$, komponen switching menggunakan IGBT tipe FGH 75 T65 UPD dan dioda yang digunakan adalah RURG 8060. Perhitungan nilai masing masing komponen berdasarkan persamaan (1) (4) [13].

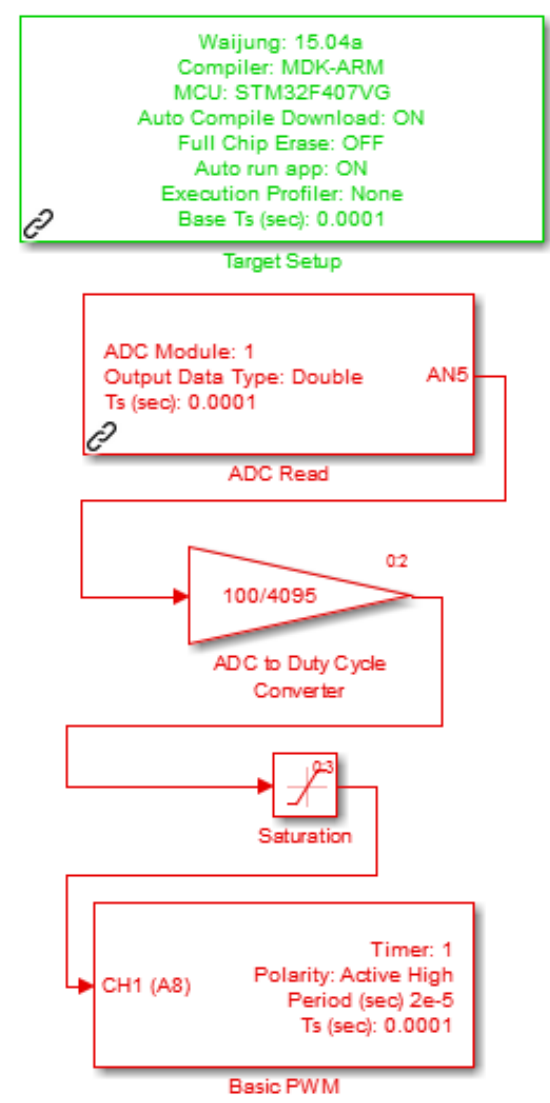

Gambar 3. Pengaturan PWM pada STM32F4 menggunakan waijung blockset - MATLAB/Simulink

Tabel 1. Parameter buck converter

\begin{tabular}{ccc}
\hline Parameter & Nilai & Satuan \\
\hline Vs & 35 & $\mathrm{~V}$ \\
Vo (max) & 31.5 & $\mathrm{~V}$ \\
Vo (min) & 3.5 & $\mathrm{~V}$ \\
Io & 5 & $\mathrm{~A}$ \\
F / T & $100 / 10$ & $\mathrm{kHz} / \mu \mathrm{s}$ \\
(switching) & & $\%$ \\
Ripple V & 0.1 & $\%$ \\
Ripple I & 10 & $\mu \mathrm{H}$ \\
Induktor & 126 & $\mu \mathrm{F}$ \\
Capacitor & 11 & $\Omega$ \\
Resistor & 12.6 & \\
\hline
\end{tabular}

Perhitungan tegangan keluaran $\left(V_{o}\right)$, tegangan masukan $\left(V_{s}\right)$ dan duty cycle (D) dinyatakan dengan persamaan (1) [14]. Pada paper ini, tegangan $V_{S}$ sebesar $35 \mathrm{~V}$ dengan $V_{o}$ sebesar 3,5 V sampai 31,5 V dengan duty cycle sebesar $25 \%$ sampai $75 \%$.

$$
V_{o}=V_{s} D
$$

Perhitungan frekuensi buck converter ditunjukkan oleh (2). Dimana $L$ adalah nilai 
induktor, $\Delta i_{L}$ adalah ripple arus pada induktor (10\% dari arus keluaran (Io) atau sebesar $0.5 \mathrm{~A}$ ) dan $f$ adalah frekuensi switching $(\mathrm{Hz})$. Berdasarkan persamaan (2), nilai induktor yang dibutuhkan adalah $126 \mu \mathrm{H}$.

$$
L=\left(\frac{V_{S}-V_{o}}{\Delta i_{L} f}\right) D
$$

Perhitungan nilai resistor pada rangkaian buck conveter pada gambar 2 ditunjukkan oleh persamaan (3). Dimana $L_{\min }$ merupakan nilai induktor minimal yang digunakan dan $R$ adalah nilai resitor dalam $\Omega$.

$$
L_{\min }=\frac{(1-D)}{2 f} R
$$

Perhitungan nilai capacitor yang digunakan mengikuti persamaan (4).

$$
C=\frac{1-D}{8 L\left(\Delta V_{o} / V_{o}\right) f^{2}}
$$

Desain rangkaian snubber pada buck converter mengikuti persamaan (5) untuk parameter Rs dan persamaan (6) untuk parameter Cs.

$$
C_{S}=\frac{I_{\text {on }} \times t_{f a l l}}{2 \times V_{o f f}}
$$

dimana $I_{o n}=I_{o}$ dan $V_{\text {off }}$ adalah tegangan offset.

$$
R_{S}=\frac{D \times T}{2 \times C_{S}}
$$

Pengujian secara eksperimen pada buck converter dilakukan dengan mengatur frekuensi switching sebesar $50 \mathrm{kHz}, 55 \mathrm{kHz}, 60$ $\mathrm{kHz}, 65 \mathrm{kHz}$ dan $70 \mathrm{kHz}$ dan mengatur duty cycle sebesar $25 \%$ sampai $75 \%$ dengan beda sebesar $5 \%$. Parameter pengamatan terdiri atas tegangan masukan, arus masukan, arus keluaran, tegangan keluaran, daya masukan, daya keluaran dan effisiensi. Pengukuran daya masukan $\left(p_{\text {in }}\right)$ mengikuti persamaan (7) sedangkan pengukuran pengukuran daya keluaran $\left(P_{\text {out }}\right)$ mengikuti persaman (8).
Berdasarkan daya masukkan dan daya keluaran, perhitungan effisiensi ditunjukkan oleh persamaan (9).

$$
\begin{gathered}
P_{\text {in }}=V_{S} x I_{S} \\
P_{\text {out }}=V_{o} x I_{o} \\
\text { effisiensi }=\frac{P_{\text {out }}}{P_{\text {in }}}
\end{gathered}
$$

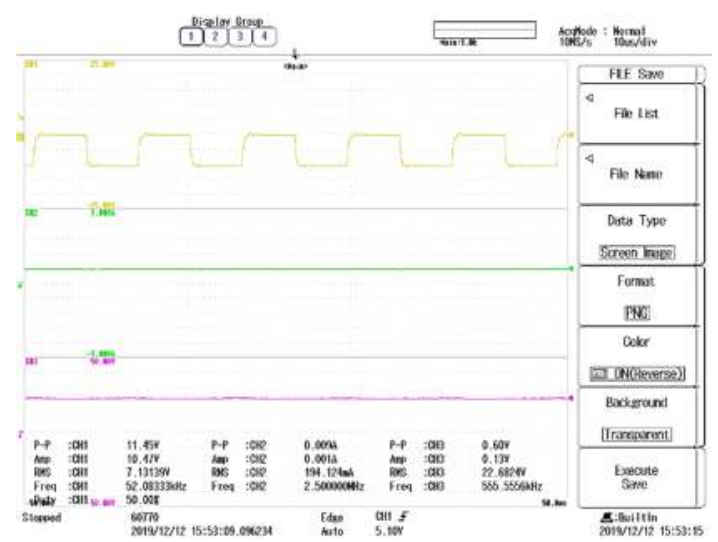

Gambar 4. Duty cycle, arus keluaran dan tegangan keluaran pada frekuensi $50 \mathrm{kHz}$ dan duty cycle $50 \%$

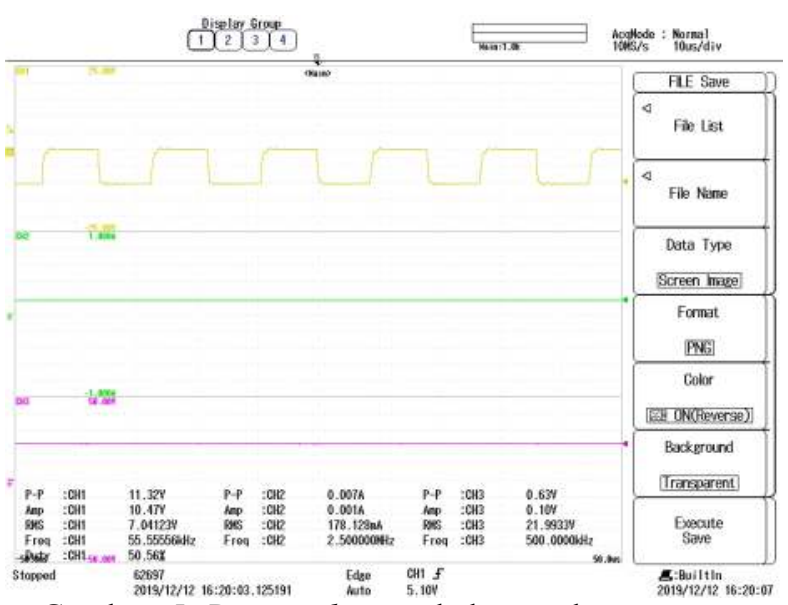

Gambar 5. Duty cycle, arus keluaran dan tegangan keluaran pada frekuensi $55 \mathrm{kHz}$ dan duty cycle $50 \%$ 


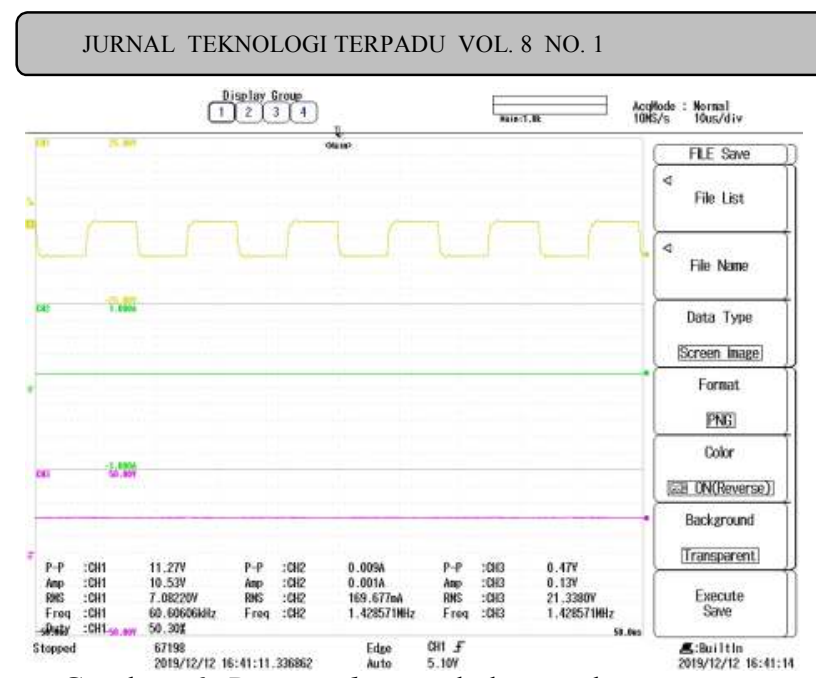

Gambar 6. Duty cycle, arus keluaran dan tegangan keluaran pada frekuensi $60 \mathrm{kHz}$ dan duty cycle 50\%

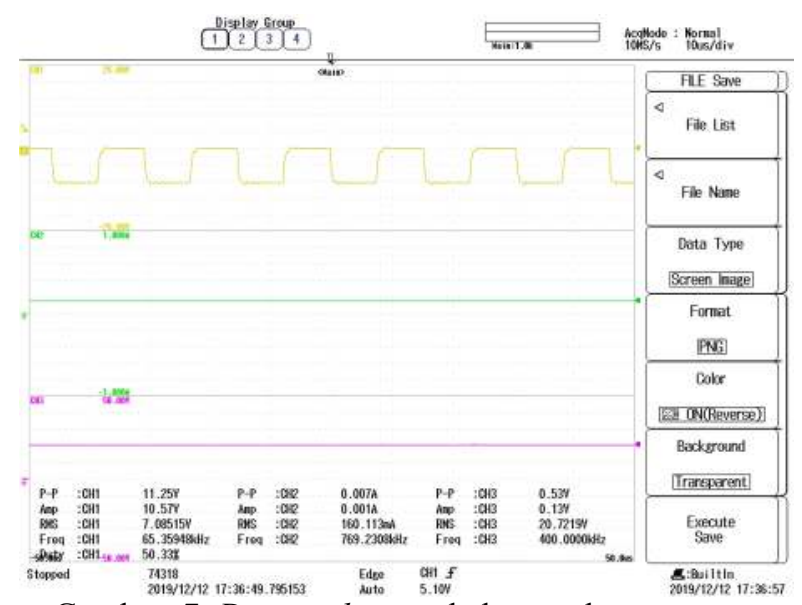

Gambar 7. Duty cycle, arus keluaran dan tegangan keluaran pada frekuensi $65 \mathrm{kHz}$ dan duty cycle $50 \%$

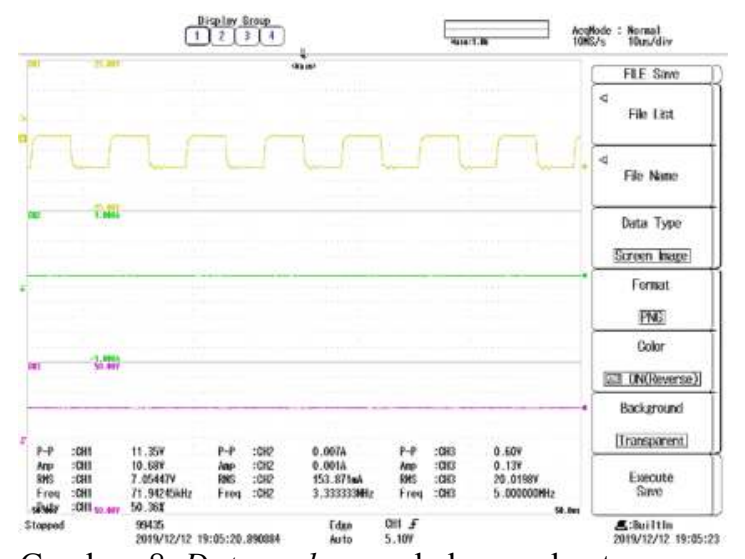

Gambar 8. Duty cycle, arus keluaran dan tegangan keluaran pada frekuensi $70 \mathrm{kHz}$ dan duty cycle $50 \%$

Pengukuran duty cycle, arus keluaran dan tegangan keluaran dari buck converter ditunjukkan oleh gambar 4-8. Pada gambar 4, frekuensi switching yang digunakan sebesar 50 $\mathrm{kHz}$ dengan duty cycle $50 \%$. Buck converter dengan frekuensi switching $55 \mathrm{kHz}$ dan duty cycle $50 \%$ ditunjukkan oleh gambar 5. Gambar 6 menunjukkan buck converter dengan frekuensi switching sebesar $60 \mathrm{kHz}$ dengan duty cycle $50 \%$. Buck converter dengan frekuensi switching $65 \mathrm{kHz}$ dan duty cycle $50 \%$ ditunjukkan oleh gambar 7, sedangkan gambar 8 menunjukkan buck converter dengan frekuensi switching $70 \mathrm{kHz}$ dengan duty cycle $50 \%$.

Pada gambar 9, respon arus masukan berban berbanding lurus dengan perubahan duty cycle. Pada duty cycle di bawah $70 \%$, besarnya arus masukan sangatlah dipengaruhi oleh perubahan frekuensi switching. Namun, untuk duty cycle diatas $70 \%$, perubahan frekuensi switching memberikan pengaruh yang tidak signifikan terhadap arus masukan. Respon tegangan keluaran buck converter pada variabel frekuensi switching dan duty cycle ditunjukkan gambar 10. Rata - rata penurunan tegangan pada rentang frekuensi switching 50 $\mathrm{kHz}-70 \mathrm{kHz}$ variabel duty cycle ditunjukkan oleh gambar 11. Berdasarkan data tersebut, prosentase penurunan terbesar pada duty cycle $40 \%$ dengan nilai 3,50\%. Respon arus keluaran buck converter ditunjukkan pada gambar 12 . Persentase penurunan rata - rata terbesar pada saat duty cycle $50 \%$ dengan persentase penurunan rata - rata sebesar $5.75 \%$.

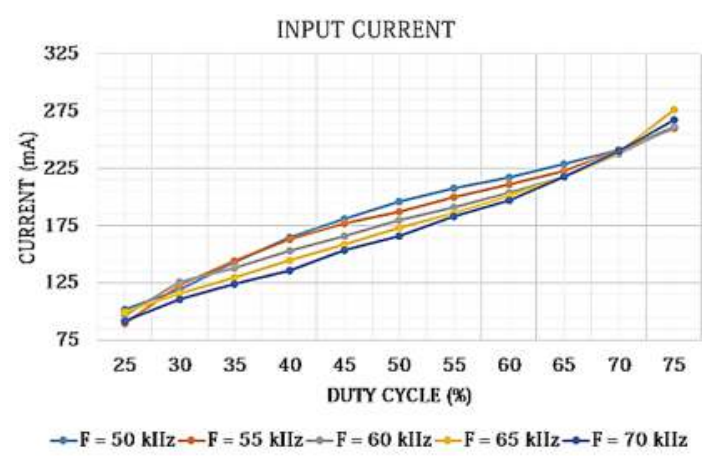

Gambar 9. Respon arus masukan pada variabel frekuensi 


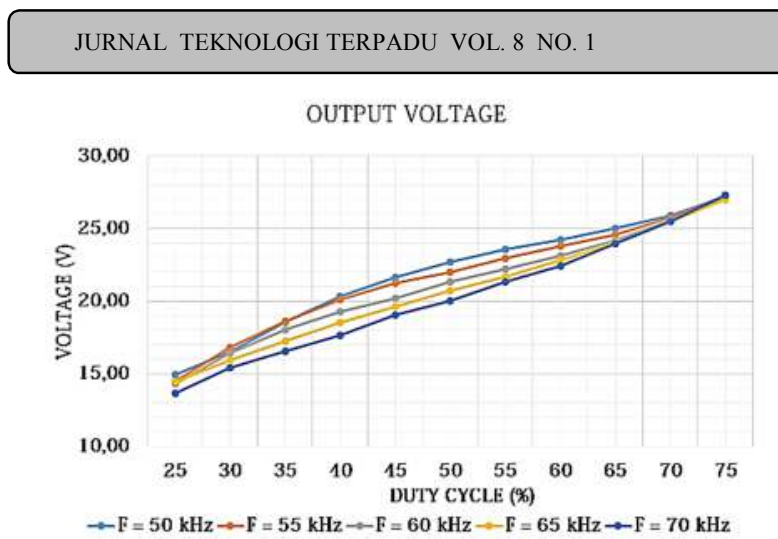

Gambar 10. Respon tegangan keluaran pada variabel frekuensi

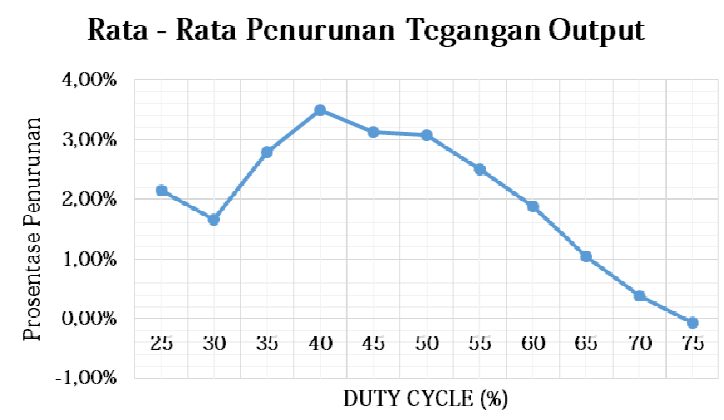

Gambar 11. Rata - rata penurunan tegangan keluaran

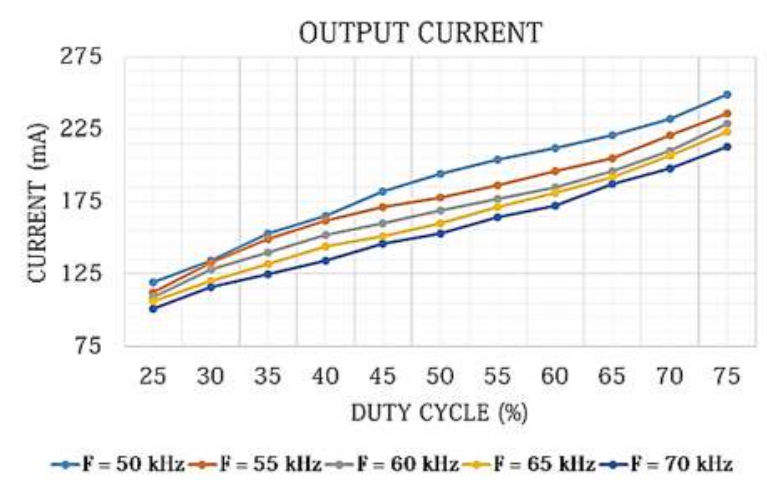

Gambar 12. Respon arus keluaran pada variabel frekuensi

Tabel 2. Hasil pengujian rangkaian buck converter dengan frekuensi $50 \mathrm{kHz}$

\begin{tabular}{ccccc}
\hline $\begin{array}{c}\mathrm{F} \\
(\mathrm{kHz})\end{array}$ & $\begin{array}{c}\mathrm{D} \\
(\%)\end{array}$ & $\begin{array}{c}\text { Pin } \\
(\text { watt })\end{array}$ & $\begin{array}{c}\text { Pout } \\
(\text { watt })\end{array}$ & $\begin{array}{c}\text { Eff } \\
(\%)\end{array}$ \\
\hline \multirow{6}{*}{50} & 25 & 3,57 & 1,77 & 49,70 \\
& 30 & 4,17 & 2,21 & 53,15 \\
& 35 & 5,01 & 2,84 & 56,74 \\
& 40 & 5,78 & 3,36 & 58,11 \\
& 45 & 6,34 & 3,93 & 62,11 \\
& 50 & 6,86 & 4,40 & 64,14 \\
& 55 & 7,28 & 4,81 & 66,08 \\
& 60 & 7,60 & 5,13 & 67,58 \\
& 65 & 8,02 & 5,53 & 68,96 \\
\hline
\end{tabular}

ISSN $2338-6649$

\begin{tabular}{llll}
70 & 8,44 & 6,00 & 71,18 \\
75 & 9,14 & 6,78 & 74,20 \\
\hline
\end{tabular}

Tabel 3. Hasil pengujian rangkaian buck converter dengan frekuensi $55 \mathrm{kHz}$

\begin{tabular}{ccccc}
\hline $\begin{array}{c}\mathrm{F} \\
(\mathrm{kHz})\end{array}$ & $\begin{array}{c}\mathrm{D} \\
(\%)\end{array}$ & $\begin{array}{c}\text { Pin } \\
(\text { watt })\end{array}$ & $\begin{array}{c}\text { Pout } \\
(\text { watt })\end{array}$ & $\begin{array}{c}\text { Eff } \\
(\%)\end{array}$ \\
\hline \multirow{6}{*}{5} & 25 & 3,15 & 1,62 & 51,52 \\
& 30 & 4,31 & 2,24 & 52,00 \\
& 35 & 5,04 & 2,77 & 54,96 \\
& 40 & 5,71 & 3,26 & 57,10 \\
& 45 & 6,20 & 3,63 & 58,63 \\
& 50 & 6,55 & 3,91 & 59,80 \\
& 55 & 7,00 & 4,27 & 61,01 \\
& 60 & 7,39 & 4,66 & 63,09 \\
& 65 & 7,81 & 5,04 & 64,59 \\
& 70 & 8,44 & 5,70 & 67,54 \\
& 75 & 9,10 & 6,41 & 70,41 \\
\hline
\end{tabular}

Tabel 4. Hasil pengujiann rangkaian buck converter dengan frekuensi $60 \mathrm{kHz}$

\begin{tabular}{ccccc}
\hline $\begin{array}{c}\mathrm{F} \\
(\mathrm{kHz})\end{array}$ & $\begin{array}{c}\mathrm{D} \\
(\%)\end{array}$ & $\begin{array}{c}\text { Pin } \\
\text { (watt) }\end{array}$ & $\begin{array}{c}\text { Pout } \\
(\text { watt })\end{array}$ & $\begin{array}{c}\text { Eff } \\
(\%)\end{array}$ \\
\hline 6 & 25 & 3,40 & 1,56 & 45,91 \\
& 30 & 4,41 & 2,10 & 47,69 \\
& 35 & 4,83 & 2,52 & 52,23 \\
& 40 & 5,36 & 2,93 & 54,75 \\
& 45 & 5,81 & 3,23 & 55,66 \\
60 & 50 & 6,30 & 3,61 & 57,25 \\
& 55 & 6,69 & 3,93 & 58,75 \\
& 60 & 7,14 & 4,28 & 59,90 \\
& 65 & 7,63 & 4,74 & 62,09 \\
& 70 & 8,33 & 5,37 & 64,46 \\
& 75 & 9,14 & 6,22 & 68,04 \\
\hline
\end{tabular}

Tabel 5. Hasil pengujian rangkaian buck converter dengan frekuensi $65 \mathrm{kHz}$

\begin{tabular}{ccccc}
\hline $\begin{array}{c}\mathrm{F} \\
(\mathrm{kHz})\end{array}$ & $\begin{array}{c}\mathrm{D} \\
(\%)\end{array}$ & $\begin{array}{c}\text { Pin } \\
(\text { watt })\end{array}$ & $\begin{array}{c}\text { Pout } \\
(\text { watt })\end{array}$ & $\begin{array}{c}\text { Eff } \\
(\%)\end{array}$ \\
\hline \multirow{6}{6}{65} & 25 & 3,50 & 1,53 & 43,70 \\
& 30 & 4,06 & 1,91 & 47,14 \\
& 35 & 4,55 & 2,28 & 50,01 \\
& 40 & 5,08 & 2,67 & 52,58 \\
& 45 & 5,57 & 2,96 & 53,18 \\
& 50 & 6,06 & 3,32 & 54,75 \\
& 55 & 6,51 & 3,71 & 57,00 \\
& 60 & 7,04 & 4,13 & 58,69 \\
& 65 & 7,63 & 4,61 & 60,39
\end{tabular}




\begin{tabular}{llll} 
JURNAL TEKNOLOGI TERPADU VOL. 8 & NO. 1 & \\
\hline 70 & 8,37 & 5,28 & 63,13 \\
75 & 9,66 & 6,01 & 62,26 \\
\hline
\end{tabular}

Tabel 6. Hasil pengujian rangkaian buck converter dengan frekuensi $70 \mathrm{kHz}$

\begin{tabular}{ccccc}
\hline $\begin{array}{c}\mathrm{F} \\
(\mathrm{kHz})\end{array}$ & $\begin{array}{c}\mathrm{D} \\
(\%)\end{array}$ & $\begin{array}{c}\text { Pin } \\
(\text { watt })\end{array}$ & $\begin{array}{c}\text { Pout } \\
(\text { watt })\end{array}$ & $\begin{array}{c}\text { Eff } \\
(\%)\end{array}$ \\
\hline \multirow{6}{*}{70} & 25 & 3,22 & 1,38 & 42,82 \\
& 30 & 3,89 & 1,79 & 46,07 \\
& 35 & 4,34 & 2,07 & 47,70 \\
& 40 & 4,76 & 2,36 & 49,63 \\
& 45 & 5,39 & 2,78 & 51,57 \\
& 50 & 5,81 & 3,06 & 52,72 \\
& 55 & 6,41 & 3,49 & 54,56 \\
& 60 & 6,90 & 3,86 & 55,98 \\
& 65 & 7,63 & 4,48 & 58,77 \\
& 70 & 8,40 & 5,05 & 60,08 \\
& 75 & 9,35 & 5,81 & 62,20 \\
\hline
\end{tabular}

Data pengujian rangkaian buck converter untuk parameter pengukuran daya masukan, daya keluaran dan effiensi pada masing masing duty cycle ditunjukkan oleh tabel 2, 3, 4, 5 dan 6 pada frekuensi switching $50 \mathrm{kHz}, 55$ $\mathrm{kHz}, 60 \mathrm{kHz}, 65 \mathrm{kHz}$ dan $70 \mathrm{kHz}$. Berdasarkan data eksperimen, perubahan duty cycle berbanding lurus dengan perubahan daya masukan, daya keluaran dan effisiensi. sedangkan, perubahan frekuensi switching berbanding terbalik dengan tegangan keluaran.

\section{Kesimpulan}

Pada paper ini, buck converter didesain berbasis STM32F4 dan MATLAB/Simulink. Tegangan masukan pada buck converter didesain sebesar $35 \mathrm{~V}$. dengan tegangan keluaran sebesar 3,5 V - 31,5 V, frekuensi switching maksimum sebesar $100 \mathrm{kHz}$, riple tegangan sebesar $0,1 \%$ dan riple arus sebesar $10 \%$. Berdasarkan data eksperimen, duty cycle berbanding lurus dengan tegangan keluaran, arus keluaran, daya keluaran dan effisiensi.

\section{Saran}

Buck converter pada paper ini dapat dikembangkan dengan menambahkan dan mengembangkan konsep HIL untuk respon tegangan keluaran, arus keluaran, daya
APRIL 2020

ISSN 2338 - 6649

keluaran dan efisiensi. Pegembangan juga dapat dilakukan dengan menambahkan kendali konvensional PID dan artificial intelligent. Buck converter dapat diaplikasikan pada pengaturan kecepatan dari motor DC. Pada segi sumber tegangan, dapat dikembangkan dengan memanfaatkan solar cell yang terintegrasi dengan jala - jala Perusahaan Listrik Negara (PLN).

\section{Daftar Pustaka}

[1] S. Sivakumar, M. J. Sathik, P. Manoj dan G. Sundararajan, "An assessment on performance of DC-DC converters for renewable energy applications," Renewable and Sustainable Energy Reviews, vol. 58, pp. 1475 - 1485, 2016.

[2] D. Spiera, G. Oggier dan S. d. Silva, "Dynamic modeling and analysis of the bidirectional DC-DC boost-buck converter for renewable energy applications," Sustainable Energy Technologies and Assessments, p. 133-145, 2019.

[3] J. R. K. dan S. Natarajan, "Energy sources and multi-input DC-DC converters used in hybrid electric vehicle applications - A review," International Journal of Hydrogen Energy, vol. 43, no. 36, pp. 17387-17408, 2018.

[4] H. Wang, A. Gaillard dan D. Hissel, "A review of DC/DC converter-based electrochemical impedance spectroscopy for fuel cell electric vehicles," Renewable Energy, vol. 141, pp. 124 - 138, 2019.

[5] T. Youssef, M. Elsied, A. Salemd, A. Oukaour, H. Gualousc dan O. Mohammeda, "Carrier extraction based synchronization scheme for distributed DC - DC converters in DC - Microgrid," Electric Power Systems Research, pp. 114 - 122, 2018.

[6] J. López, S. S. Jr., P. Donoso, L. Morais, P. Cortizo dan M. Severo, "Digital control strategy for a buck converter operating as a battery charger for stand-alone photovoltaic 
systems," Solar Energy, pp. 171 - 187, 2016.

[7] G. Ma, B. Wang, D. Xu dan L. Zhang, "Switching control strategy based on nonsingular terminal sliding mode for buck converter in auxiliary energy source," dalam Energy Procedia, Tianjin, 2018.

[8] R. Inanlou, R. Shokri, O. Shoaei dan A. Baschirotto, "A Buck Converter Based On Dual Mode Asynchronous Pulse Width," AEU - International Journal of Electronics and Communications, 2019.

[9] P.-Y. Kuo dan Q.-J. Zhuang, “Analyze Buck Converter with PWM Feedback Circuit Using Matlab Simulink tool," dalam IEEE International Conference on Consumer Electronics-Taiwan (ICCE-TW), Taichung, 2018.

[10] G. A. Ramos, M. E. Hernández dan M. D. Trujillo, "Function Test by HIL for DC-DC converters type: Buck, Boost and BuckBoost," dalam International Workshop on Power Electronics \& Power Quality Application, Bogota, 2017.

[11] M. Truntic dan M. Milanovic", "Voltage and Current-Mode Control for a Buck-Converter based on Measured Integral Values of Voltage and Current Implemented in FPGA," IEEE TRANSACTIONS ON POWER ELECTRONICS, vol. 29, no. 12, pp. 6686 - 6699, 2014.
[12] J. Mina, Z. Flores, E. Lopez, A. Perez dan J. -H. Calleja, "Processor-in-the-loop and hardware-in-the-loop simulation of electric systems based in FPGA," dalam 13th International Conference on Power Electronics (CIEP), Guanajuato, 2016.

[13] D. -I. P. Ballesteros, P. D.-I. C. Bohn dan P. D.-I. C. Rembe, Rapid Control Prototyping Using an STM32 Microcontroller, Clausthal-Zellerfeld: TU Clausthal, 2015.

[14] D. W.Hart, Power Elecronics, New York: McGraw-Hill, 2011. 